\title{
ANALYSIS OF USING OF SOCIAL MEDIA AS COMMUNICATION FOR LECTURES AT PTKIN: Case Study of Da'wa Management of IAIN Sultan Amai Gorontalo and IAIN Pare-Pare
}

\author{
Dian Adi Perdana 1 , Afidatul Asmar ${ }^{2}$ \\ ${ }^{1}$ Sultan Amai State Islamic Institute, Gorontalo, 2 Pare-Pare State Islamic Institute \\ 1dianadiperdana@iaingorontalo.ac.id, 2afidatulasmar@iainpare.ac.id
}

\begin{abstract}
Social media is a tool that cannot be separated from modern human life, regardless of age, location, profession, and status. Every message can be sent quickly and right to other people both short and far distances. The covid-19 outbreak makes everyone do social distancing to minimize the spread of the virus, including teaching and learning activities at schools and campuses. This research discusses social media that has used by students and lecturers in their online learning with various platforms directed by lectures or campus that occurred in students of the Da'wa Management department at IAIN Sultan Amai Gorontalo and IAIN Pare-Pare. This discussion aims to determine the analysis use the social media during the online learning period which has occurred in the last semester, so it will provide benefits to researchers and intellectuals to explore and learn effective ways of organizing online learning in the future. This study used a descriptive qualitative method that occurred in two different places (IAIN Sultan Amai Gorontalo and IAIN Pare-pare. The researcher collected data by observation, documentation, and interviews with several structured and non-structured questions. The data that has been collected and analyzed by the researcher to give conclusions from the problems that have been found. The results of this study indicate that the use of social media as communication for online lectures in the Da'wa Management Department of IAIN Sultan Amai Gorontalo and IAIN Pare-Pare is effective with several notes related to minor numbers on students' understanding of the material, personal enjoyment, influencing attitudes, social relations between students and lecturers. students and personal actions during the Covid-19 pandemic.
\end{abstract}

Keywords: Da'wa management; communication; social media

Abstrak: Media sosial adalah sarana yang tidak bisa dilepas dari kehidupan manusia modern saat ini, tanpa memandang usia, lokasi, profesi bahkan status. Setiap pesan dapat disampaikan dengan cepat dan tepat kepada orang lain baik jarak dekat maupun jarak pendek. Adanya wabah covid-19 ini telah memaksakan setiap manusia melakukan social distancing guna meminimalisir penyebaran virus tersebut, tak terkecuali dengan kegiatan belajar mengajar di sekolah dan kampus. Penelitian ini membahas media sosial yang telah lama digunakan para mahasiswa kepada dosennya di saat kegiatan kuliah daring (online) dengan menggunakan berbagai platform yang telah diarahkan oleh para dosen maupun pihak kampus yang terjadi pada mahasiswa/i Jurusan Manajemen Dakwah di dua PTKIN yakni IAIN Sultan Amai Gorontalo dan IAIN Pare-Pare. Pembahasan ini bertujuan untuk mengetahui efektifitas penggunaan media sosial selama masa perkuliahan daring yang telah terjadi satu semester terakhir sehingga akan memberikan manfaat kepada para peneliti maupun kaum intelektual untuk mendalami dan mempelajari cara yang efektif dalam penyelenggaraan kuliah daring di beberapa waktu ke depan. Penelitian ini menggunakan metode kualitatif deskriptif dengan menggunakan pendekatan studi kasus yang terjadi di dua tempat yeng berbeda, yang kemudian peneliti mengumpulkan data-data dengan observasi, wawancara dan juga dokumentasi dengan beberapa pertanyaan terstruktur dan non terstruktur. Data-data yang telah diperoleh, dianalisa guna disajikan secara optimal oleh peneliti dengan memberikan kesimpulan dari permasalahan yang telah ditemukan. 
Hasil penelitian ini bahwa penggunaan media sosial sebagai komunikasi kuliah daring di Jurusan Manajemen Dakwah IAIN Sultan Amai Gorontalo dan IAIN ParePare efektif dengan beberapa catatan terkait angka minor terhadap pengertian mahasiswa pada materi, kesenangan personal, mempengaruhi sikap, hubungan sosial diantara mahasiswa dan dosen-mahasiswa serta tindakan personal di masa pandemi Covid-19.

Kata Kunci: Manajemen dakwah; komunikasi; media sosial

\section{A. Introduction}

The development of technology and information is so fast and rapid, sometimes even difficult to control for those who are reluctant to keep up with the times. The most basic thing is the existence of the internet with various advantages and speeds that can be used in various activities of human life. Communication without the internet is like eating rice without side dishes, which means that the internet has become an important part of communication in society, both interpersonal communication, intercultural communication, to communication between communities, which does not impose boundaries and always provides wide space for its users. Communication via the internet can be accessed using cell phones or cellphones, computers and laptops, with a connection device or connector that becomes a bridge to get a signal to facilitate internet access wherever and whenever.

In this modern era, we can be sure that almost all people in this world own and utilize the internet, especially through cellular phones or handphones. The use of the internet in various activities has become a common practice in communicating, it's just how a person can use it properly and optimally so as to avoid the abyss of humiliation. In ancient times, everyone was always limited by time and space to communicate with each other, then with the development of this technology space and time were not the main problems. The internet is the focus that is used in a device, in which there is a medium that can connect people to strengthen social relationships. This media allows users to represent themselves in interacting, cooperating, sharing, communicating with other users to form virtual social bonds (Nasrullah: 2015).

Social media is a means that cannot be separated from modern human life today, regardless of age, location, profession and even status. Each message can be conveyed quickly and precisely to other people both short and short distances. One of the benefits of social media as a source of information through various existing platforms and applications such as Facebook, Twitter, Instagram, YouTube, Telegram, WhatsApp, Line and others is by creating an account as a personal identity to facilitate access to it without being restricted by anything. Social media that is supported by good internet services and optimal networks will further strengthen the relationship between the owner and the device, internet users will be more comfortable doing activities on their social media. The convenience obtained is a personal alternative in finding answers related to social problems.

In a study conducted by We Are Social in 2019 (www.databoks.katadata.co.id) It is stated that telephone users are 355.5 million out of Indonesia's 268.2 million population, which means that telephone users are more than the total population. It can also be said that there are some people who have 2 or more telephones that are used to make it easier to communicate with other parties. Of the 355.5 million telephone users, there are only 150 million people who use the internet and are active on social media, this figure consists of 20 million active users of social media on computers or laptops and 130 million active users of social media via telephone. cellular or mobile. The use of social media as a learning technology, entertainment media, communication media, to a forum for discussion in finding solutions and making decisions in dealing with problems in society. The following is a diagram of telephone, internet and social media users in Indonesia: 


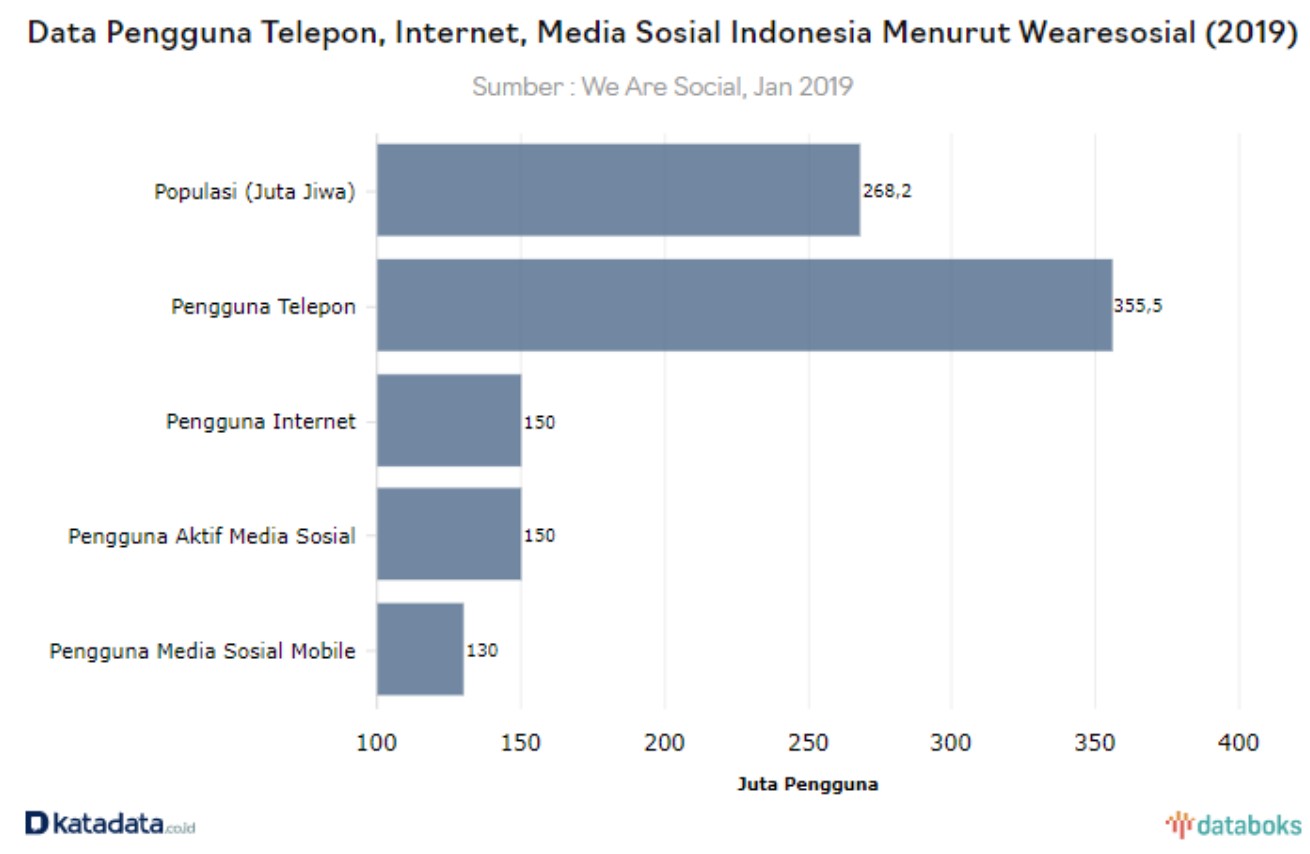

Figure 1: www.databoks.katadata.co.id

A social problem that is currently spreading is the covid-19 outbreak which has forced every human being to carry out social distancing to minimize the spread of the virus, including teaching and learning activities at schools and campuses. The Covid-19 outbreak has occurred since the end of 2019, with the largest cases in China with 81,620 cases (www.worldmeters.info). Meanwhile in Indonesia, as of April 2, 2020, 170 people died, 1,790 were positive and 112 recovered (www.covid19.go.id), This makes Indonesia and even the world take a preventive attitude with social distancing in various places such as not holding gatherings in public places, using masks and always washing hands. Social media plays an important role in socializing social distancing and provides important education to the entire community in an effort to spread this virus.

Schools and campuses as media for public gatherings must also be temporarily shifted to social media as a follow-up to a more effective and efficient teaching and learning process in the Covid-19 era. Although various effects arise from the online or online teaching and learning process, this does not discourage continuing education and sharing knowledge among teacherstudents and lecturer-students. Various social media are used to facilitate both parties, so as to minimize conflicts that will arise. Social media can reach all elements of society both in villages and in cities, but it can affect personal emotional which then can hinder communication, with the existence of an unsupportive environment and habits such as minimal network and no cell phone due to low economy. The teaching and learning process must inevitably be carried out with the coercion of existing conditions with appropriate and optimal actions.

Social media has become a new tool and even a new weapon in carrying out various missions in order to create an optimal succession, including in the field of education at the primary, secondary to tertiary levels. The involvement of various elements in communicating through social media has become a special concern in building good relationships between individuals. According to Nasrullah (2015) The presence of social media and the growing number of users from time to time have provided an interesting fact about the enormous power and impact of the internet on lives. Various facts that emerge both in the form of information and news in various aspects through social media, have made it a phenomenon in this modern era. Phenomena in the field of education also appear continuously, with the response of the 
community through social media that has made it a viral thing and even trending topics on various platforms.

The world of education has gradually adapted to the use of social media, especially supported by the age of education which is classified as a teenager. Nur Ainiyah (2018) said that social media has brought and shaped a new world in the mindset of millennial adolescents in interacting and communicating in new ways, especially in the world of education, which of course as students expect a media that facilitates the educational process, and without realizing it, social media has become the answer. Social media provides educational messages such as Wikipedia and so on, and social media as a medium of liaison between teenagers who are building networks and acquaintances so that they can be used in the future both in business, politics and in society.

\section{B. Theoretical Review}

According to Hamzah (2015) Education supported by social media is the development of online learning technology, which is a complementary method for traditional educational learning. The social media used by students to their lecturers will strengthen collaboration and collaboration between individuals, which then supports the smoothness of the academic learning process. Social media is a solution for the academic world with limited physical documents or paper used in every academic activity, so that students and lecturers can interact with digital documents that can be accessed by both parties without any restrictions. Apart from digital documents, other media that can be accessed in the form of video, audio, and e-mail as an introduction to messages, even now lecturers and students can video call each other using several platforms that have regenerated their systems.

Suryadi et al (2018) According to him, the use of social media, namely WhatsApp on the discipline of learning of students, has a strong positive effect, especially on the subject of Islamic Religious Education, this is due to the large number of students using social media, namely WhatsApp during class hours, so that the learning discipline of students becomes weak and not focus on following the lesson. Hanoum (2014) In his research, the use of social media in learning is very useful in increasing the active participation of students in the learning process, which will ultimately have an impact on learning outcomes. This can happen because social media users, namely students, use it as a place to share information, discussions and other activities which are often constrained by limited time in class.

Based on some of the research above, social media is an interesting thing in interpersonal connectivity, from students to lecturers, lecturers to students and fellow students, so that this research discusses the use of social media by students to their lecturers during online lectures using various platforms such as Facebook, Twitter, Instagram, YouTube, Telegram, WhatsApp, Line and others which have been directed by lecturers and the campus in particular. at the State Islamic Religious College (PTAIN) during the covid-19 period. Social media is a form of communication used by many people, this communication will run and be considered effective, if it raises these 5 things, namely understanding, fun, influencing attitudes, good social relations and actions (Tubbs et al: 2002).

With some of the descriptions above, this study discusses the analysis of the use or use of social media as a means of communication during online lectures at 2 PTAINs, namely the Sultan Amai State Islamic Institute (IAIN) and the State Islamic Institute (IAIN) Pare- Pare by focusing on 1 study program, namely Da'wa Management on both campuses. What social media are used during online lectures at the Sultan Amai Gorontalo State Islamic Institute (IAIN) and the ParePare State Islamic Institute (IAIN); and How effective is the use of social media as communication between the two parties (lecturers and students) during online lectures at the Sultan Amai State Islamic Institute (IAIN) in Gorontalo and the Pare-Pare State Islamic Institute (IAIN). 


\section{Methods}

This research is a research that uses a descriptive qualitative method with a case study approach that occurs in 2 locations. The data collection techniques used were observation, interviews and documentation, with a focus on interview techniques and structured and nonstructured questions in the questionnaire as a research tool. Interviews were conducted to extract data from sources by filling out a questionnaire that had been prepared by the researcher. According to Moelong (1993) Research with interview techniques as data mining and filling out questionnaires by respondents aims so that the results obtained can be used in research to achieve research objectives and targets, based on questionnaires that have been prepared previously.

Researchers conducted direct interviews with respondents with questions and answers that had been prepared in the questionnaire as an interview guide. The data that has been obtained from respondents through questionnaires that have been filled in, then analyzed in order to be presented optimally by the researcher by providing conclusions from the problems that have been found. In this study the researchers conducted interviews with $10 \%$ of the total students in the Da'wa Management Study Program from 2 PTAIN campuses, namely the Sultan Amai Gorontalo State Islamic Institute (IAIN) and the Pare-Pare State Islamic Institute (IAIN) regarding the analysis of social media as lecture communication. online throughout the covid-19 outbreak, namely within 2 months from 1 July 2020 to 31 August 2020.

\section{Results and Discussion}

Da'wa management is a social scientific cluster developed in state and private universities in Indonesia. The management of Da'wa at the Sultan Amai State Islamic Institute (IAIN) in Gorontalo is under the auspices of the Faculty of Ushuluddin and Da'wa and was established in 2013, with a vision of "Making the Department of Da'wa Management a Center for the Development of Excellent Da'wa Management Science" and the following mission:

1. Carry out a process of scientific transformation in the field of da'wa management in an effective and updated manner, and integrated with science and culture.

2. Conduct research and development of knowledge in the field of da'wa management based on local culture and information technology.

3. Carry out community service in the form of da'wa practice and the application of research results and establish collaborative relationships between institutions.

Meanwhile, the Management of Da'wa at the State Islamic Institute (IAIN) Pare-Pare is under the auspices of the Faculty of Ushuluddin, Adab and Da'wa and was established in 2014, with a vision of "Carrying Out Management of Da'wa Management Based on Acculturation and Information Technology in Eastern Indonesia in 2025" and the following mission:

1. Organizing the tri dharma of higher education that is competitive and has character towards the stability of faith, moral maturity and professional stability based on information technology in the field of da'wa management.

2. Organizing Islamic acculturation studies with the cultural treasures of the archipelago in the field of da'wa management.

3. Realizing professional human resources, with an entrepreneurial spirit through integrated Islamic studies in the field of da'wa management.

The student population of the State Islamic Institute (IAIN) Sultan Amai Gorontalo Da'wa Management Study Program in the 2019/2020 even academic year was 106 people and as many as 106 students of the Pare-Pare State Islamic Institute (IAIN) Da'wa Management Study Program in the 2019/2020 even academic year are 323 students. In this study, it was obtained an average of more than $10 \%$ of the total population of each campus as follows: 

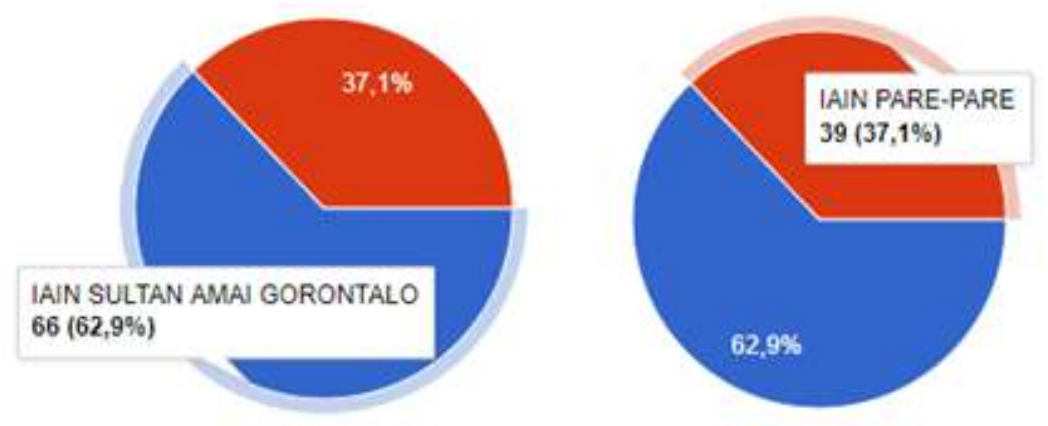

Figure 2: Student population who have filled out the questionnaire (2020)

Based on the data above, as many as 105 speakers were obtained with a composition of 66 students of IAIN Sultan Amai Gorontalo Da'wa Management (62.2\% of the 106 students) and 39 students of IAIN Parepare Da'wa Management (12\% of 323 students). With a total of 105 resource persons, if classified by age group, it is obtained as follows:

Table 1: Informant Age Group (2020)

\begin{tabular}{|c|c|c|}
\hline Age & Student & Percent (\%) \\
\hline 18 & 24 & 22,9 \\
\hline 19 & 25 & 23,8 \\
\hline 20 & 25 & 23,8 \\
\hline 21 & 17 & 16,2 \\
\hline 22 & 5 & 4,8 \\
\hline 23 & 5 & 4,8 \\
\hline$>23$ & 4 & 3,8 \\
\hline Amount & 105 & 100 \\
\hline
\end{tabular}

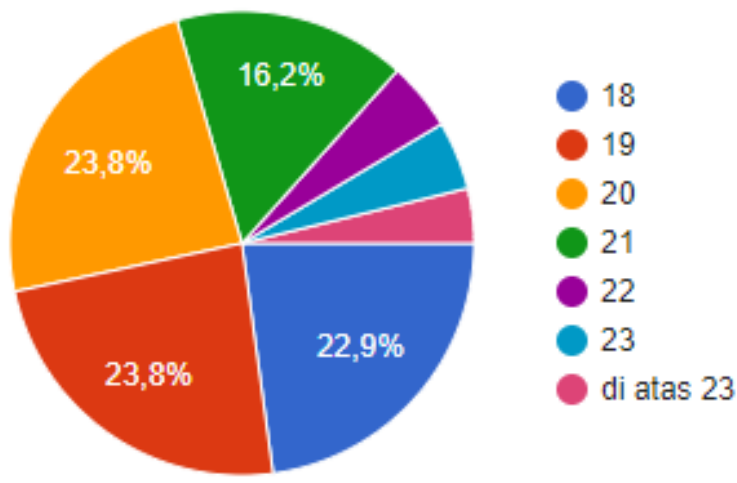

Figure 3: Informant Age Group (2020)

As many as 105 resource persons are active users of social media, if classified according to the platforms most often used in surfing in cyberspace, Facebook is found as a social media with the most $80 \%$ used as follows:

Table 2: Use of the Platform (2020)

\begin{tabular}{|c|c|c|}
\hline Platform & Students & $\begin{array}{c}\text { Percent } \\
\mathbf{( \% )}\end{array}$ \\
\hline Facebook & 15 & 14,3 \\
\hline Instagram & 6 & 5,7 \\
\hline Line & 0 & 0 \\
\hline Whatsapp & 84 & 80 \\
\hline Telegram & 0 & 0 \\
\hline dll & 0 & 0 \\
\hline Amount & 105 & 100 \\
\hline
\end{tabular}

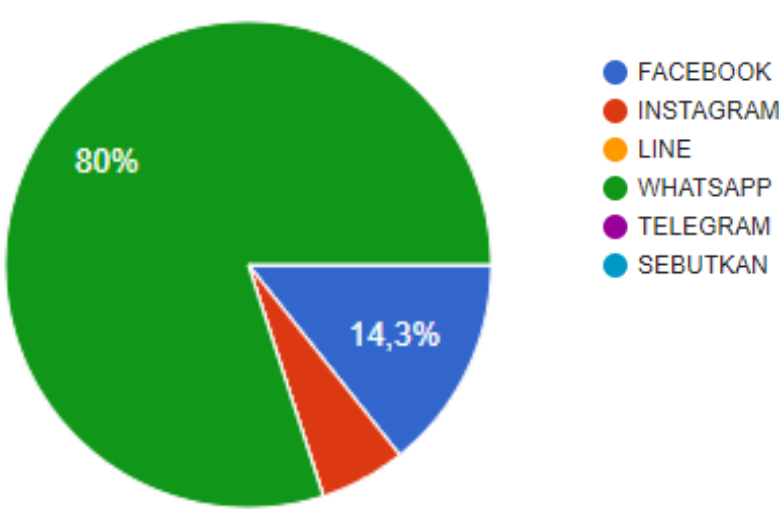

Figure 4: Use of the Platform (2020) 
In the teaching and learning process during the Covid-19 period, various applications have been used as learning support media that are maximally utilized to achieve optimal goals, so that the knowledge and knowledge conveyed by lecturers can be understood by students properly. From the data of 105 informants, it was found that the majority of students undergoing online lectures using the Whatsapp application as much as $43.8 \%$, as for other applications used in the learning process, namely edlinks of $13.4 \%$, if classified according to the learning media application used, it is obtained as follows:

Table 3: Use of Learning Applications (2020)

\begin{tabular}{|c|c|c|}
\hline Aplication & Students & Percent (\%) \\
\hline Zoom & 39 & 37,1 \\
\hline $\begin{array}{c}\text { Google } \\
\text { Meet }\end{array}$ & 6 & 5,7 \\
\hline Cloud X & 0 & 0 \\
\hline Whatsapp & 46 & 43,8 \\
\hline Telegram & 0 & 0 \\
\hline dll & 14 & 13,4 \\
\hline Amount & 105 & 100 \\
\hline
\end{tabular}

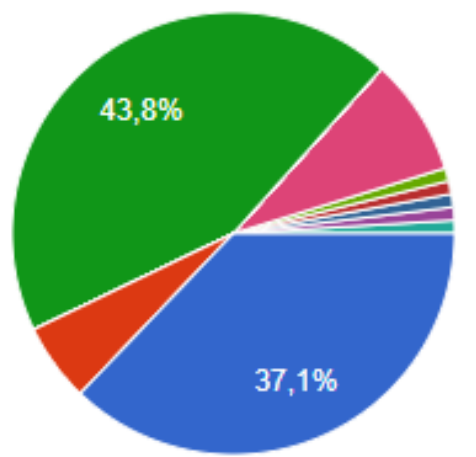

ZOOM GOOGLE MEET CLOUDX WHATSAPP TELEgRAM SEBUTKAN

Lecturer learning methods so much, so that students also receive material and discussion with varying percentages, even students who always get boredom are found to be preceded by minimal material. In the data obtained, the majority of lecturers gave a balanced portion of assignments and materials, $54.3 \%$ stated that they received this balanced portion. Of the 105 sources, it was obtained as follows:

Table 4: Lecturer to Student Teaching Pattern (2020)

\begin{tabular}{|c|c|c|}
\hline Type & Students & Percent (\%) \\
\hline $\begin{array}{c}\text { 50\% Duty \& 50\% } \\
\text { Theory }\end{array}$ & 57 & 54,3 \\
\hline $\begin{array}{c}\text { 25\% Duty \& 75\% } \\
\text { Theory }\end{array}$ & 15 & 14,3 \\
\hline $\begin{array}{l}\text { 75\% Duty \& 25\% } \\
\text { Theory }\end{array}$ & 31 & 29,5 \\
\hline $\begin{array}{l}\text { 100\% Duty } \\
\text { (Without Theory) }\end{array}$ & 1 & 1 \\
\hline $\begin{array}{c}\text { 50\% Theory } \\
\text { (Without Duty) }\end{array}$ & 1 & 100 \\
\hline Amount & 105 & \\
\hline
\end{tabular}

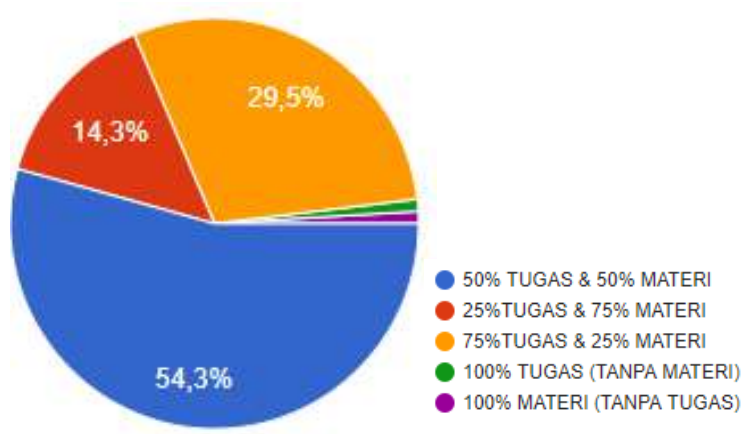

Figure 6: Lecturer to Student Teaching Pattern (2020)

Social media can be said to be effective as a communication medium during online lectures which is also a learning medium during the Covid-19 period, it can be based on 5 things, the first is that there is an understanding. In the process of communicating online lectures, students understand and understand the material presented by the lecturer, and the lecturer also provides understanding and understanding of the material presented to students in online lectures properly. From 105 sources, It was found that $61 \%$ of students agreed that during online lectures the lecturer had provided understanding and understanding of the material 
presented well and $44.8 \%$ of students were doubtful about their understanding of the material presented by the lecturer. After the interview can be obtained as follows:
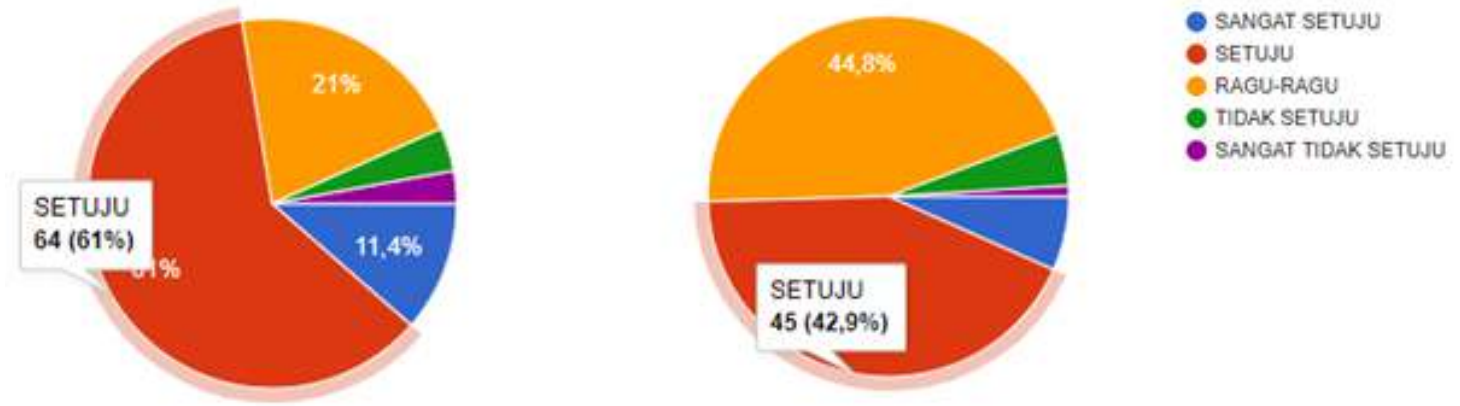

Figure 7: Definition of Lecturer to Student Teaching and Student Understanding to Lecturers (2020)

Happiness or pleasure is the second thing that makes social media effective as a medium of communication during online lectures during the Covid-19 period, as long as communicating online lectures, namely lecturers always provide a happy atmosphere in every online lecture meeting session, and students feel happy at every online lecture meeting session. As many as 105 resource persons, it was obtained that $56.2 \%$ of students agreed that during online lectures the lecturer had provided happiness at every meeting and $41.9 \%$ of students were doubtful or could be said to be quite happy during online lectures. Researchers obtained the following data:
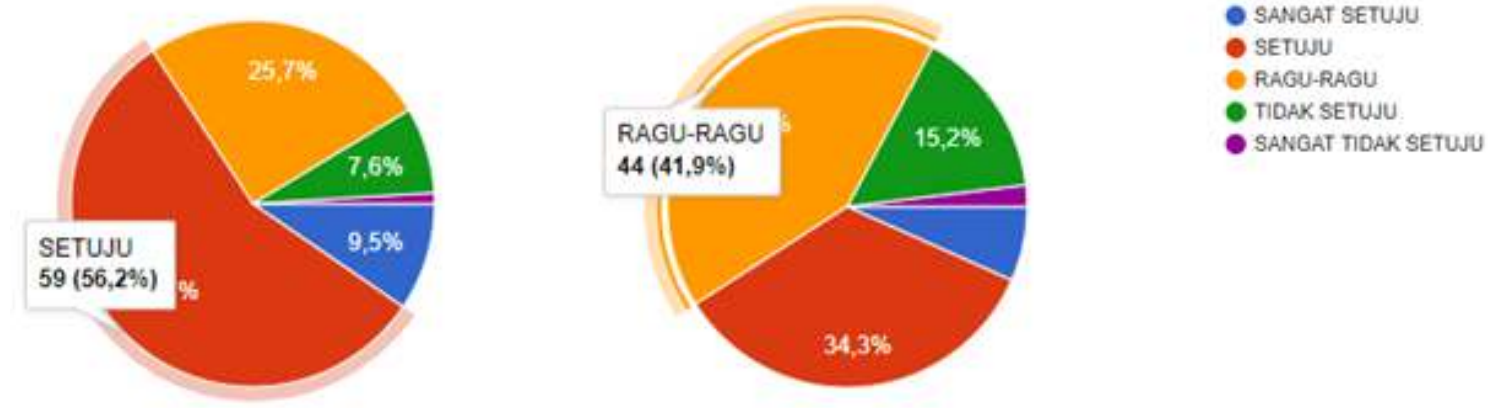

Figure 8: Happiness that Students Get and Feel for Every Online Lecture (2020)

The third aspect that makes social media effective as a medium of communication during online lectures during the Covid-19 period is the influence on the attitudes of messages delivered by lecturers to students. There are 2 things to pay attention to in this aspect, namely the material presented by the lecturer which influences the good attitude of students in every online lecture session, and students feel there is a change in attitude (to positive) during online lectures. It has been obtained from 105 students that as many as 59\% of students agree that the material presented by the lecturer has an effect on good attitudes on students in each online lecture session and $49.5 \%$ of students agree that there is a change in attitude (to positive) during online lectures.

Changes in attitudes and felt by students during online lectures include more polite speech, time discipline, more health care, more diligent in doing assignments and the teaching and learning process, implementation of knowledge directly to the community, motivated and enthusiastic in carrying out social activities, being more obedient to both parents and getting closer to family and utilizing social media or cell phones to learn optimally. The data obtained are as follows: 

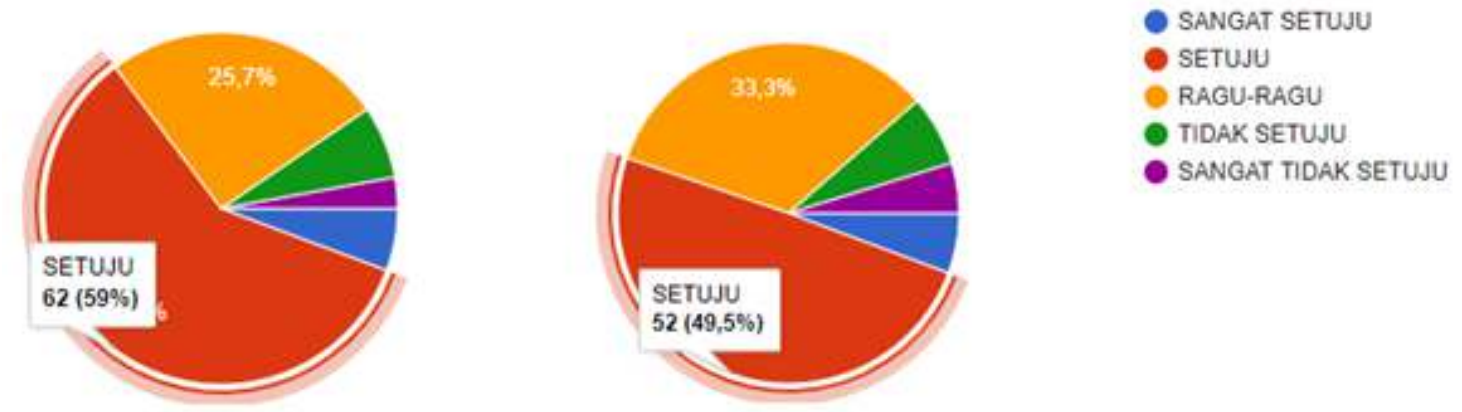

Figure 9: The Effect of Attitude Changes Acquired and Felt by Students during Online Lectures (2020)

The next thing that makes social media effective as a medium of communication during online lectures during the covid-19 period is between students and students and students to lecturers or otherwise good social relations are built. The following are the things to consider in this aspect, namely the lecturer building good social relations with students in every online lecture session, the absence of conflicts that are born during online lectures (between lecturers and students), and (fellow students). It was found that from 105 students stated that $66.7 \%$ of students agreed that lecturers build good social relationships with students in every online lecture session, $59 \%$ of students agreed that there was no conflict that was born during online lectures (between lecturers and students) and 59\% of students agreed not there is a conflict that was born during online lectures (fellow students). The following data are obtained as follows:
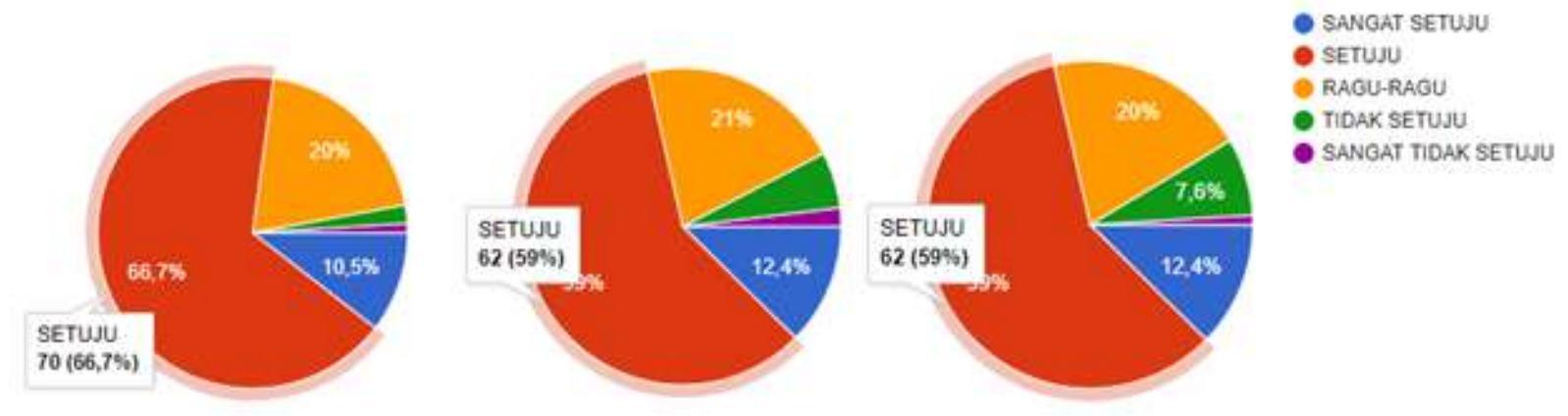

Figure 10: Social Relations of Lecturers, Absence of Conflict (Lecturers \& Students) and (Fellow Students) (2020)

The last thing that is the focus of social media can be said to be effective as a medium of communication during online lectures during the Covid-19 period is the presence of patterns of actions and characters related to lecture material. There are several things to consider in this pattern of action, namely the lecturer teaches the patterns of action and character in each material presented to students in each online lecture session, as well as the patterns of student daily actions influenced by the material presented by the lecturer during online lectures. As many as 105 students thought that 59\% of students agreed that the lecturer taught the patterns of action and character in each material presented to students in each online lecture session, and $43.8 \%$ of students agreed that the student's daily action patterns were influenced by the material presented by the lecturer during online lectures. The data obtained by researchers are as follows: 

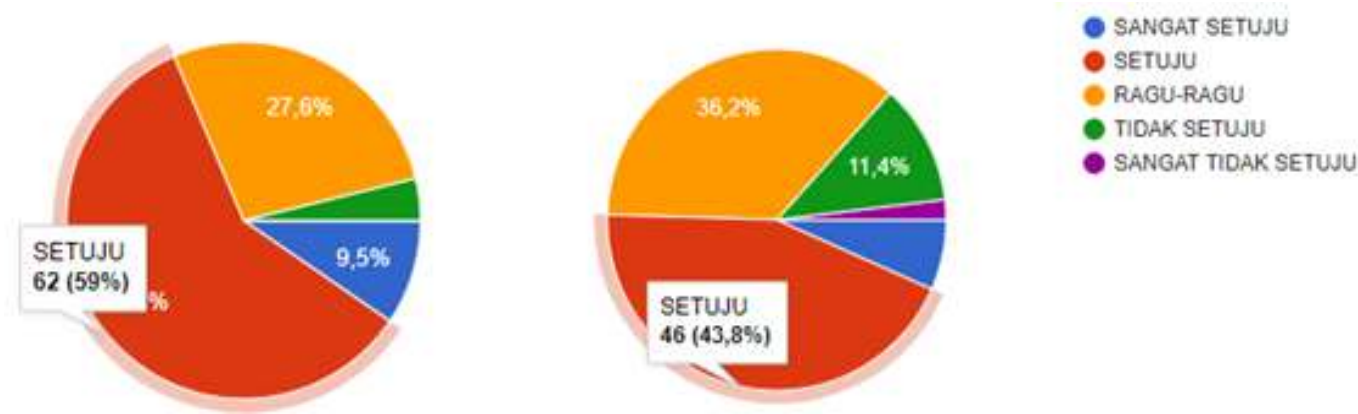

Figure 11: Action and Character Education, as well as the Implementation of Actions by Students (2020)

5 things, namely understanding, pleasure or happiness, influencing attitudes, good social relations and actions obtained by students during online lectures are a statement on the analysis of using social media as online lecture communication that occurs on 2 PTAIN campuses, namely the Sultan's State Islamic Institute (IAIN) Amai Gorontalo and the State Islamic Institute (IAIN) Pare-Pare. In fact, as many as $78.1 \%$ or 82 people stated that the application during online lectures through social media has been used by lecturers to facilitate them such as whatsapp, zoom, google meet and edlink for several reasons, namely increasing individual independence, applying disciplined life for life healthy and stop the spread of the covid-19 virus, teaches learning habits wherever and whenever.

Meanwhile, only $21.9 \%$ or 23 people stated that social media does not facilitate the teaching and learning process based on several reasons, namely the lack of provider networks, especially in rural areas, lectures not face-to-face with lecturers further reduce inner bonds in the delivery of knowledge, frequent electricity blackouts alternately in some areas, especially rural areas, the lack of hardware devices to support lectures such as laptops and androids that are capable.

\section{E. Conclusion}

Social media as an effective means of communication, especially in the online lecture process, provides several benefits even though it is not optimal, namely the delivery of understanding and understanding of material from lecturers to students and students are more independent learning to understand the material presented with limited space and time. The learning process still has a happy and enjoyable impact, especially on students, which will reduce the feeling of boredom due to the adaptation of new learning methods. Communication through social media which is used for online lectures has an effect on changing attitudes in students both within the family and in community life. The existence of social relations is maintained both by lecturers to students and fellow students so that harmonization in learning is still well maintained. As well as the delivery of messages through virtual actions for the development of student character can still be delivered.

\section{References}

Ainiyah, Nur. "Remaja Millenial dan Media Sosial: Media Sosial Sebagai Media Informasi Pendidikan bagi Remaja Millenial". Jurnal Pendidikan Islam Indonesia 2, no. 2 (2018): 221236.

Hamzah, Radja Erland. "Penggunaan Media Sosial di Kampus dalam Mendukung Pembelajaran Pendidikan". Jurnal Wacana 14, no. 1 (2015): 45-70.

Hanoum, R Nadia. "Mengembangkan Keterampilan Berpikir Tingkat Tinggi Mahasiswa Melalui Media Sosial”. Jurnal Edutech 1, no. 3 (2014): 400-408.

Moeloeng, Lexy J. Metode Penelitian Kualitatif. Bandung: Rosdakarya, 1993. 
Nasrullah, Rulli. Media Sosial; Persfektif Komunikasi, Budaya, dan Sosioteknologi. Bandung: Simbiosa Rekatama Media, 2015.

Suryadi, Edi, M Hidayat Ginanjar dan M Priyatna. "Penggunaan Sosial Media Whatsapp dan Pengaruhnya terhadap Disiplin Belajar Peserta Didik pada Mata Pelajaran Agama Islam". Jurnal Edukasi Islam 7, no. 1 (2018.): 1-22.

Tubbs, Stewart L dan Sylvia Moss. Human Communication: Principles and Contexts. McGraw-Hill Humanities, 2002.

"Berapa Pengguna Media Sosia Indonesia", https://databoks.katadata.co.id, "Data Publish We Are Social 2019". Accessed on October 23, 2020.

"Coronavirus Statistics China," https://www.worldometers.info/coronavirus/country/china/. Accessed on October 21, 2020.

"Covid-19 Indonesia,", https://www.covid19.go.id/; "Covid-19 Coronaviruses Pandemic." Accessed on October 21, 2020. 